\title{
PERAN KOMUNIKASI KELUARGA DALAM KEMANDIRIAN ANAK BERKEBUTUHAN KHUSUS TUNA GRAHITA DI YAYASAN RUMAH BERSAMA
}

\author{
Amalia Lathifah Hidayat ${ }^{1}$, Maulana Rezi Ramadhana ${ }^{2}$ \\ Prodi Ilmu Komunikasi, Fakultas Komunikasi dan Bisnis, Telkom University \\ Email: amalialathifah3@gmail.com
}

\begin{abstract}
ABSTRAK
Penelitian ini membahas tentang bagaimana peran komunikasi keluarga pada orientasi percakapan dan orientasi konformitas dalam meningkatkan kemandirian anak berkebutuhan khusus tuna grahita di Yayasan Rumah Bersama. Tujuan dari penelitian ini adalah untuk mengetahui peran komunikasi keluarga pada orientasi percakapan dan orientasi konformitas dalam meningkatkan kemandirian anak berkebutuhan khusus tuna grahita di Yayasan Rumah Bersama. Penelitian ini menggunakan teori utama Family Communication Patterns Theory dari Koerner \& Fitzpatrick 2006. Paradigma yang digunakan adalah konstruktivisme dengan pendekatan fenomenologi. Metode penelitian yang digunakan adalah kualitatif. Subjek penelitian dalam penelitian ini orang tua dari anak berkebutuhan khusus tuna grahita di yayasan rumah bersama. Teknik pengumpulan data menggunakan wawancara dan observasi. Hasil penelitian ini menunjukkan bahwa peran komunikasi keluarga dalam kemandirian anak berkebutuhan khusus tuna grahita menggunakan pola komunikasi protective families karena ditandai adanya dengan keluarga dengan orientasi percakapan yang rendah dan orientasi konformitas tinggi diberi label protektif.
\end{abstract}

Kata Kunci: Kemandirian, Pola Komunikasi, Tuna grahita

\section{THE ROLE OF FAMILY COMMUNICATION IN INDEPENDENCE CHILDREN'S SPECIAL NEED FOR MENTALLY DISABLED AT YAYASAN RUMAH BERSAMA}

\begin{abstract}
This study discusses how the role of family communication in orientation conversation and orientation conformity in increasing the self reliance of children with special needs with mental disabilities at the Yayasan Rumah Bersama. The purpose of this study was to see the role of family communication on orientation conversation and orientation conformity in increasing the self reliance of children with special needs with mental disabilities at Yayasan Rumah Bersama. This study uses the main theory of Family Communication Patterns Theory from Koerner \& Fitzpatrick 2006. The paradigm used is constructivism with a phenomenological approach. The research method used is qualitative. Research subjects in the study of parents of children with special needs with mental retardation at the Yayasan Rumah Bersama. Data collection technique using interviews and observations. The results of this study indicate that the role of family communication in the independence of children with special needs with mental disabilities uses communication patterns that protect the family because it consists of families with a low orientation conversation and a high orientation conformity labeled protective.
\end{abstract}

Keywords: Family Communication Pattern, Independence, Mentally disabled 
Korespondensi: Amalia Lathifah Hidayat. Prodi Ilmu Komunikasi, Fakultas Komunikasi dan Bisnis, Telkom University. Alamat: Jl. Telekomunikasi Jl. Terusan Buah Batu, Sukapura, Kec. Dayeuhkolot, Kota Bandung, Jawa Barat 40257. Email: benisamuhammad@gmail.com

\section{PENDAHULUAN}

Tidak semua manusia dilahirkan dalam keadaan normal, namun terdapat beberapa individu yang dilahirkan dalam keterbatasan kemampuan (disability) baik cacat mental maupun cacat fisik. Berkaitan dengan sebutan disability, hingga anak berkebutuhan khusus merupakan anak yang memiliki keterbatasan di salah satu ataupun sebagian dari kemampuannya baik itu yang bersifat fisik semacam tunarungu serta tunanetra, ataupun yang bersifat psikologis semacam autism, ADHD, serta tuna grahita. Riset ini berfokus pada peran komunikasi keluarga dalam kemandirian anak berkebutuhan khusus tuna grahita.

Menurut Kosasih 2012 dalam jurnal (Ummah, 2018), mengatakan bahwa ABK adalah anak yang lamban, kemudian mengalami kendala tidak dapat berhasil apabila bersekolah di sekolah umum lainnya. Anak yang mengalami gangguan pada mental, fisik, intelegensi, dan emosi disebut dengan anak berkebutuhan khusus (ABK) maka dari itu membutuhkan pendidikan secara khusus. ABK merupakan anak yang berbeda dengan anak normal pada umumnya. Sehingga ABK dianggap memerlukan dorongan spesial karena mereka dianggap sosok yang tidak berdaya. Setiap anak memiliki kekurangan dan kelebihan nya masing-masing. ABK membutuhkan atensi, baik melalui kasih sayang, pembelajaran ataupun hubungan sosial sehingga akan terbentuk dan meningkatkan bakat potensial yang dimilikinya.

Jumlah penyandang disabilitas di Indonesia pada tahun 2010 sebanyak 11,580,117 jiwa. Dengan beragam kategori diantarnya tunanetra (3,474,035 jiwa), disabilitas fisik (3,010,830 jiwa), tunarungu (2,547,626 jiwa), retardasi mental (1,389,614 jiwa), dan disabilitas kronis (1,158,012 jiwa) (Organization, 2010). Pada tahun 2015 jumlah penyandang disabilitas di Indonesia menurut SUPAS adalah 21,84 juta jiwa (Kustiani, 2019). Kemudian pada tahun 2018 jumlah penduduk di Indonesia penyandang disabilitas menurut SUSENAS sebanyak 30,38 juta jiwa (Al Ansori, 2020). Menurut World Bank pada tahun 2020 terdapat satu miliar orang, atau 15\% dari populasi dunia, yang mengalami beberapa bentuk disabilitas, dan prevalensi disabilitas lebih tinggi terdapat di negara berkembang. Seperlima dari perkiraan total global, atau antara 110 juta dan 190 juta orang, mengalami disabilitas yang signifikan (Basaninyenzi, 2020). Dilihat dari data pada tahun 2010, 2015, 2018, dan 2020 artinya jumlah penyandang disabilitas yang ada di Indonesia dan di dunia mengalami peningkatan yang signifikan di setiap tahun nya.

Tuna grahita adalah anak yang disebut dengan retardasi mental atau anak yang mengalami keterbelakangan mental. Menurut Mangunsong 2009 dalam jurnal (Mayasari, 2019) America Association on Mental Retardation mengungkapkan anak yang memiliki tingkat kecerdasan dibawah rata-rata yaitu 70 , kemudian mengalami kesulitan dalam berperilaku adaptif dan biasanya terjadi pada usia dibawah 18 tahun merupakan anak dengan keterbelakangan mental. Karakteristik khusus yang dimiliki oleh anak tuna grahita yang dapat membedakan dengan anak lain seusianya. Pada anak tuna grahita perilaku adaptasi yang dimaksud 
seperti kemampuan dalam berkomunikasi, mengarahkan diri sendiri, memiliki keterampilan sosial, dapat menggunakan sarana umum, menjaga dirinya sendiri, dan fungsi pada akademik (Ramawati, 2012).

Menurut (Widiastuti \& Winaya, 2019) anak tuna grahita yang ringan dapat di klasifikasikan ke dalam anak yang memiliki sedikit dalam ketergantungannya seperti masih dapat untuk belajar dalam membaca, berhitung dengan sederhana, bahkan menulis. Untuk mendapatkan hasil yang baik perlu adanya bimbingan dan didikan yang diberikan kepada anak tuna grahita ringan. Sedangkan menurut menurut (Davidson \& Kroll, 1991) anak tuna grahita sedang dan berat dibutuhkan adanya pelatihan khusus dalam menguasai keterampilan tertentu. Sehingga dapat disimpulkan bahwa anak tuna grahita ringan dapat dikatakan lebih mudah untuk dilatih dalam kegiatan sehari-hari termasuk bina diri sedangkan untuk anak tuna grahita sedang dan berat yang akan memerlukan waktu dalam menguasai segala hal yang dipelajari nya.

Keluarga ialah ranah untuk anak dalam memusatkan dalam berkembang serta membentuk individu sesuai dengan apa yang diharapkan orang tua. Anak akan tumbuh dan berkembang menjadi individu yang berbeda-beda sesuai dengan cara yang dilakukan anak dalam mengambil sikap pada lingkungan sekitarnya dan pembelajaran yang diberikan oleh orang tua. Di sisi lain, tiap orang tua tentu mengin ginkan kedatangan seseorang anak yang sempurna tanpa kekurangan sedikitpun baik mental maupun fisiknya. Namun apa yang di harapkan terkadang tidak sesuai dengan realitas dan seluruh yang di idamkan oleh rencana manusia. Anak berkebutuhan khusus juga memiliki hak yang sama dengan anak normal lain nya untuk mendapatkan pendidikan (Mayasari, 2019).

Teori pola komunikasi adalah teori komunikasi yang kuat berdasarkan model kognisi sosial yang canggih dan sudah terbukti relevan dengan sejumlah keluarga merupakan proses penting, seperti ketakutan komunikasi Elwood \& Schrader (dalam Koerner \& Fitzpatrick, 2006). McLeod dan Chaffee (dalam Koerner \& Fitzpatrick, 2006) mengembangkan model lainnya pada pola komunikasi keluarga untuk menggambarkan keinginan dalam mengembangkan bagaimana melakukan komunikasi yang cukup stabil dalam keluarga. McLeod dan Chaffee tidak tertarik pada komunikasi keluarga sebagai tujuan itu sendiri. Sebaliknya, mereka ingin menjelaskan bagaimana keluarga menciptakan dan berbagi dalam realitas sosial. Dengan demikian mereka memiliki hasrat untuk menjelaskan bagaimana orang tua bersosialisasi dengan anak nya untuk dapat mengolah informasi yang didapat dari luar keluarga. Pengertian komunikasi keluarga menurut Rosnandar (1992:4) dalam jurnal (Awi et al., 2016) dimana satu proses dalam penyampaian pesan kepada anggota keluarga yang bertujuan untuk dapat mempengaruhi dan membentuk sikap sesuai pesan yang disampaikan komunikator yaitu orang tua.

Activity of Daily Living (ADL) adalah istilah yang digunakan untuk secara kolektif menggambarkan keterampilan dasar yang diperlukan untuk merawat diri sendiri seperti makan, mandi, dan mobilitas lainnya. Istilah ini pertama dicetuskan oleh Sidney Katz pada tahun 1950 dalam jurnal (Edemekong et al., 2017). Activity daily living (ADL) menurut Efendi dalam jurnal (Hutasoit \& Sartika, 2018) setiap individu dituntut agar dapat hidup mandiri oleh orang tua. Tujuan nya adalah agar setiap individu tidak bergantung kepada 
orang lain di sekitarnya. Setiap orang tidak akan muncul kemandirian secara tiba-tiba tanpa diberikan adanya pemahaman dan latihan sejak kecil. Memberikan pendidikan yang tepat merupakan salah satu cara yang tepat dalam membangun kemandirian pada ABK. Karena ABK memiliki hak yang sama dengan anak normal lainnya dalam bidang pendidikan, pekerjaan untuk masa depan dan lainnya. Pada anak usia sekolah kemandirian yang dilakukan adalah tugas-tugas dalam perkembangan nya seperti makan, berbicara, belajar, kontak perasaan dengan lingkungan sekitar, kordinasi tubuh, dan pengertian moral. Salah satu syarat anak dapat dikatakan sudah memenuhi kemandirian adalah mampu melakukan tugas pengembangan nya. Begitu pun dengan anak tuna grahita akan mengalami ketergantungan jika tidak diberikan pelatihan dalam aktivitas sehari-harinya. Pada saat mengurangi ketergantungan serta keterbatasan yang dialami anak tuna grahita hendak meningkatkan kemandirian dalam hidup bermasyarakat, semacam keahlian dalam melaksanakan perawatan dirinya sendiri tanpa dorongan orang lain bisa dicoba dengan metode membagikan pembelajaran spesial, latihan-latihan, serta membagikan pengetahuan aktivitas kehidupan tiap hari.

ABK tuna grahita merupakan salah satu ABK yang memiliki kekurangan yaitu salah satunya adalah dalam merawat dirinya (E. Kurniawan, 2012). Penelitian terdahulu menunjukan bahwa, orang tua memiliki peran penting pada setiap tahap perkembangan anaknya sehingga dapat mencapai kemandirian. Anak berkebutuhan khusus memiliki banyak keragaman yang dapat membawa dampak pada kebutuhan nya. Melaksanakan Activity of Daily Living (ADL) merupakan salah satu dari kebutuhan ABK (Apsari, 2015). Berdasarkan temuan yang terdapat pada penelitian terdahulu lainnya menunjukkan bahwa, guru sudah menawarkan program latihan kepada para orang tua untuk menjalankan nya di rumah agar anak dapat mandiri. Akan tetapi orang tua hanya menjalankan sekali saja program latihannya, kemudian orang tua kembali memanjakan anak dan mendidik anak secara bebas sesuai apa yang disukai nya. Orang tua akan hanya beberapa kali saja mengikuti saran yang sudah diberikan, tetapi orang tua kembali mulai memanjakan anak sehingga membuat anak menjadi tergantungan kepada orang tuanya (Wiryadi, 2014).

Fenomena ini didukung dengan pendapat dari Ketua Ikatan Psikologi Klinis Indria Lasmi Gamayanti, menjelaskan orang tua di Indonesia tidak tega dan terlalu sayang kepada ABK sehingga mereka tidak melatih kemandirian dan kembali memanjakan anaknya (Aulia, 2016). Hasil penelitian yang telah dilakukan oleh Ulfatulsholihat 2010 dalam jurnal (Rahmatika \& Apsari, 2020), bahwa keinginan untuk dapat hidup mandiri dan tidak selalu bergantung kepada orang lain juga dirasakan oleh anak tuna grahita. Selain itu anak tuna grahita juga memiliki keinginan untuk dianggap sama dengan anak normal lainnya. Hal tersebut terjadi karena anak tuna grahita selalu menginginkan apa yang dimiliki oleh anak normal pada umumnya. Sehingga dapat dilihat salah satu harapan yang dimiliki oleh anak tuna grahita adalah kemandirian seperti untuk dapat mengurus diri sendiri sehingga tidak selalu bergantung kepada orang disekitarnya, dan diajarkan untuk dapat memiliki rasa tanggung jawab dalam pengembangan dirinya.

Penelitian ini menggunakan paradigma konstruktivis sosial, dimana peneliti akan mengumpulkan data secara kualitatif yang diolah secara deskriptif dengan menggunakan pendekatan fenomenologi. Paradigma 
konstruktivis dipilih karena peneliti bertujuan untuk membahas proses interaksi dan komunikasi yang terjadi antara anak berkebutuhan khusus tuna grahita dengan orang tua. Pengumpulan data diperoleh melalui proses wawancara terhadap orang tua dari anak berkebutuhan khusus tuna grahita di Yayasan Rumah Bersama yang terletak di Perum PMI 2 Blok F No.19 Pangulah Utara, Kota Baru, Kabupaten Karawang, Jawa Barat 41374. Alasan pemilihan Yayasan Rumah Bersama dijadikan sebagi tempat untuk melakukan penelitian karena dilihat berdasarkan keunikan yang dimiliki oleh Yasayan Rumah Bersama. Berdasarkan informasi yang di dapat melalui media cetak koran Radar Karawang edisi hari Kartini, pada awal nya Yayasan Rumah Bersama dibangun atas tingginya rasa kepedulian yang dimiliki oleh pemilik kepada ABK karena menurutnya anak berkebutuhan khusus masih kurang dari perhatian pemerintah setempat. Pemilik menjadikan ruang tamu dan garasi rumah nya untuk menjadi tempat bersekolah anak-anak berkebutuhan khusus. Yayasan ini dibangun sejak tahun 2011 namun hingga saat ini belum mendapatkan bantuan dari pemerintah daerah. Adapun tujuan dari penelitian ini adalah untuk mengetahui peran komunikasi keluarga pada orientasi percakapan dan orientasi konformitas dalam meningkatkan kemandirian anak berkebutuhan khusus tuna grahita di Yayasan Rumah Bersama.

\section{METODE PENELITIAN}

Pada penelitian ini, peneliti menggunakan metode penelitian kualitatif. Penelitian kualitatif merupakan sebuah metode dalam pendekatan dan mengeksplorasi serta memahami makna dari individu maupun kelompok yang terkait dengan manusia atau masalah sosial.

Penelitian ini menggunakan pendekatan fenomenologi. Pendekatan fenomenologi merupakan pendekatan yang diawali oleh Edmund Husserl serta dibesarkan oleh Martin Heidegger buat menguasai ataupun menekuni pengalaman hidup manusia. Pendekatan ini berevolusi suatu tata cara riset kualitatif yang matang serta dewasa selama beberapa dekade pada abad ke 2 puluh. Fokus umum penelitian ini buat mengecek atau mempelajari esensi ataupun struktur pengalaman ke dalam pemahaman manusia (Tuffour, 2017).

\section{Paradigma Penelitian}

Pada penelitian ini, peneliti menggunakan paradigma konstuktivis. Di konstruktivis, konten yang tidak dapat dipisahkan dari komunikasi, kenyataan dibangun melalui komunikasi. Teori pembelajaran konstruktivis dengan demikian sangat mirip dengan sosiologis Gagasan seperti konstruksi sosial realitas (Littlejohn \& Foss, 2009:598).

Penelitian ini menggunakan paradigma konstruktivis karena peneliti mencoba untuk memahami dan mengetahui tentang bagaimana peran komunikasi keluarga dalam kemandirian anak berkebutuhan khusus tuna grahita pada siswa-siswi di yayasan rumah bersama.

\section{Subjek dan Objek Penelitian}

Subjek dari penelitian ini adalah orang tua dari anak berkebutuhan khusus tuna grahita di Yayasan Rumah Bersama. Objek dari penelitian ini adalah peran komunikasi keluarga. 


\section{Lokasi Penelitian}

Penelitian ini dilakukan di Yayasan Rumah Bersama yang terletah di Perum PMI 2 Blok F No.19 Pangulah Utara, Kota Baru, Kabupaten Karawang, Jawa Barat 41374.

\section{Unit Analisis Penelitian}

Unit analisis dan sub analisis yang digunakan dalam penelitian sebagai berikut:

\begin{tabular}{|c|c|}
\hline Unit Analisis & Sub Analisis \\
\hline $\begin{array}{c}\text { Pola } \\
\text { Komunikasi } \\
\text { Keluarga }\end{array}$ & $\begin{array}{ll}\text { 1. } & \text { Orientasi } \\
\text { Percakapan } \\
\text { 2. } & \text { Orientasi } \\
\text { Konformitas }\end{array}$ \\
\hline
\end{tabular}

\section{Informan Penelitian}

Pada penelitian ini memiliki karakteristik informan yaitu orang tua yang memiliki ABK tuna grahita yang berusia 9-16 tahun, orang tua yang memiliki ABK kategori berat dan ringan. orang tua yang memiliki ABK tuna grahita yang bersedia untuk memberikan informasi atau keterangan kepada peneliti.

\section{Teknik Pengumpulan Data}

\section{Wawancara}

Menurut (Yusuf, 2016:372), wawancara merupakan pengumpulan data dengan mengajukan pertanyaan kepada informan untuk mengumpulkan data dalam penelitian yang dilakukan secara tatap muka.

\section{Observasi}

Menurut (Yusuf, 2016:384), bahwa, observasi digunakan untuk memperoleh suatu data atau bukti-bukti yang valid dalam pelaksanaan penelitian dengan memperhatikan subjek dan objek penelitian. Pada penelitian ini menggunakan Participant Observer merupakan dimana pengamat ikut terjun langsung ke dalam kegiatan yang diamatinya.

\section{Teknik Analisis Data}

Menurut Muhammad Idrus (dalam skripsi Alhafid 2018:37-38), teknik analisis data dalam penelitian deskriptif kualitatif lebih kearah pada model interaktif Huberman dan Miles yaitu Tahap pengumpulan data, reduksi data, display data, dan verivikasi data.

\section{Teknik Keabsahan Data}

Dalam penelitian peran komunikasi keluarga dalam kemandirian anak berkebutuhan khusus tuna grahita di Yayasan Rumah Bersama, yang digunakan dalam teknik keabsahan data adalah triangulasi sumber. Terdapat berbagai cara dalam Triangulasi menurut Bachri BS dalam jurnal (Mekarisce 2020):

a. Triangulasi Sumber

Merupakan mengecek ulang atau membandingkan tingkat kepercayaan suatu informasi yang sudah didapat melalui sumber yang berbeda.

b. Triangulitas Metode 
Merupakan bentuk usaha yang dilakukan untuk melihat keabsahan data atau temuan yang didapat oleh peneliti. Teknik ini dapat dilakukan lebih dari satu teknik dalam pengumpulan data untuk mendapatkan hasil yang sama.

c. Triangulasi Waktu

Diterapkan untuk melakukan validasi data yang dapat berkaitan dengan adanya perubahan dari proses dan perilaku manusia. Untuk mendaptakan data yang valid peneliti tidak bisa melakukan observasi atau pengamatan hanya sekali saja.

\section{HASIL DAN PEMBAHASAN}

Setelah melakukan wawancara terhadap informan utama, maka peneliti mendapatkan data-data yang diperlukan untuk penelitian ini. Lalu data-data yang diperoleh peneliti diolah dan dianalisis menjadi bentuk pola komunikasi keluarga dalam kemandirian anak berkebutuhan khusus tuna grahita.

Wawancara yang dilakukan dalam sehari pada hari Senin yaitu tanggal 19 Oktober 2020 di Yayasan Rumah Bersama Cikampek, Jawa Barat. Peneliti melakukan wawancara secara langsung dengan informan utama pada hari masuk sekolah dan berlokasi di aula yayasan dengan sesuai protokol kesehatan agar peneliti dapat mengamati secara langsung kegiatan belajar-mengajar di yayasan tersebut.

Sesuai dengan pembahasan penelitian yang ditulis, peneliti akan mendeskripsikan bagaimana bentuk pola komunikasi orangtua dalam kemandirian anak berkebutuhan khusus tuna grahita. Sehingga akan diketahui cara orang tua dalam melatih bina diri anak berkebutuhan khusus yang pada akhirnya dapat membangun kemandirian pada anak berkebutuhan khusus tersebut. Adapun bentuk pola komunikasi yang akan dianalisis antara lain orientasi percakapan dan orientasi konformitas. Peneliti menjabarkan hasil penelitian yang telah diperoleh melalui wawancara pada uraian dibawah ini.

Orientasi Percakapan

Topik: Orientasi Percakapan

Main Question: Bagaimana peran orang tua sebagai komunikator dalam menyampaikan pesan kepada ABK.

Tabel 1. Rekapitulasi Hasil Wawancara

\begin{tabular}{cclc}
\hline \multicolumn{1}{c}{ Nama } & \multicolumn{2}{c}{ Peran Indikator } & Penyampaian Pesan \\
\hline $\begin{array}{c}\text { Titin Supriat \& } \\
\text { Marjoko }\end{array}$ & - & $\begin{array}{l}\text { Komunikasi dilakukan tidak intens. } \\
\text { kemberikan pertanyaan berulang-ulang } \\
\text { kepanak nya. }\end{array}$ & $\begin{array}{c}\text { Selalu bertanya kepada anak nya apa } \\
\text { yang diinginkan nya. }\end{array}$ \\
\hline Siti Halimah & - & $\begin{array}{l}\text { Komunikasi dilakukan secara intens. } \\
\text { Memberikan pertanyaan berulang-ulang } \\
\text { kepada anak nya. }\end{array}$ & $\begin{array}{c}\text { Selalu berusaha berinteraksi dengan } \\
\text { anak. }\end{array}$ \\
\hline Imas Rohila & - & $\begin{array}{l}\text { Komunikasi dilakukan tidak intens. } \\
\text { Memberikan pertanyaan berulang-ulang } \\
\text { kepada anak nya. }\end{array}$ & $\begin{array}{c}\text { Dengan cara memberikan fasilitas } \\
\text { kepada anak untuk berkomunikasi. }\end{array}$ \\
\hline Rosita Herawati & Komunikasi dilakukan tidak intens. & Dengan cara mengawasi aktivitas \\
\end{tabular}


Hasil yang di dapat melalui wawancara dengan keempat informan utama adalah peran orang tua sebagai komunikator dalam menyampaikan pesan kepada ABK tuna grahita dengan memberikan pertanyaan berulang-ulang kepada anak nya. Kemudian tiga keluarga menerapkan low conversation didalam keluarga ditandai dengan komunikasi yang dilakukan tidak intens kepada ABK tuna grahita, dan satu keluarga menerapkan high conversation yang ditandai dengan komunikasi yang dilakukan secara intens dengan ABK tuna grahita. Kemudian dalam penyampaian pesan yang dilakukan orang tua kepada anak berkebutuhan khusus tuna grahita dilakukan secara inisiatif.

Orientasi percakapan didefinisikan ditandai dengan sejauh mana keluarga dalam menciptakan iklim seluruh anggota keluarga agar ikut berpartisipasi tidak terkendali antara dengan interaksi beragam topik. Dalam keluarga di tempat yang tinggi, pada akhir dimensi anggota keluarga akan bebas dalam berinteraksi satu sama lain tanpa batasan dalam waktu dan topik yang dibahas akan secara spontan dan sering menurut (Koerner \& Fitzpatrick, 2006). Ketiga keluarga dari empat informan utama memiliki orientasi percakapan yang rendah dengan ditandai adanya sikap anggota keluarga yang jarang berinteraksi dan membahas beberapa topik secara terbuka. Faktor yang membuat ketiga keluarga tersebut jarang melakukan komunikasi karena terkendala anak yang masih belum lancar dalam berbicara dan anak yang lebih asik dengan dunia nya sendiri, kemudian kendala yang dirasakan orang tua jarang melakukan komunikasi karena orang tua memiliki kesibukan diluar. Kemudian satu keluarga memiliki orientasi percakapan yang tinggi yang ditandai dengan sikap anggota keluarga yang lebih bebas, sering, dan secara spontan berinteraksi satu sama lain tanpa banyak batasan waktu yang dihabiskan, atau topik yang dibahas.

Berdasarkan hasil data wawancara pada keempat orang tua anak berkebutuhan khusus tuna grahita di Yayasan Rumah Bersama, di dapat bahwa satu keluarga telah menerapkan dimensi percakapan yang tinggi (high conversation), artinya orang tua sering melakukan interaksi dan komunikasi dengan anak berkebutuhan khusus tuna grahita dalam melatih kemandirian dengan seperti membimbing dalam melakukan aktivitas sehari-hari. Sedangkan ketiga keluarga menerapkan dimensi percakapan yang rendah (low conversation), artinya orang tua jarang melakukan komunikasi dengan anak berkebutuhan khusus tuna grahita karena orang tua memiliki kesibukan dan anak yang cenderung asik dengan dunia nya sendiri.

\section{Orientasi Konformitas}

\section{Topik: Orientasi Konformitas}

Main Question: Bagaimana peran orang tua sebagai komunikator dalam menyampaikan pesan kepada ABK. 
Tabel 2. Rekapitulasi Hasil Wawancara

\begin{tabular}{|c|c|c|}
\hline Nama & Peran Indikator & Penyampaian Pesan \\
\hline $\begin{array}{l}\text { Titin Supriat } \\
\& \text { Marjoko }\end{array}$ & 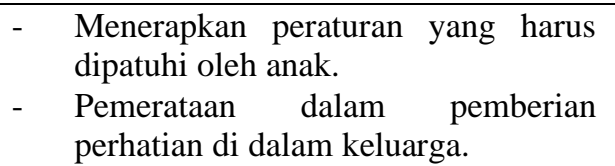 & $\begin{array}{l}\text { Menerapkan disiplin tinggi untuk } \\
\text { menumbuhkan kebiasaan baik } \\
\text { pada anak. }\end{array}$ \\
\hline Siti Halimah & 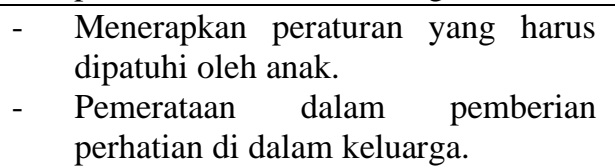 & $\begin{array}{l}\text { Menerapkan disiplin tinggi untuk } \\
\text { menumbuhkan kebiasaan baik } \\
\text { pada anak. }\end{array}$ \\
\hline Imas Rohila & 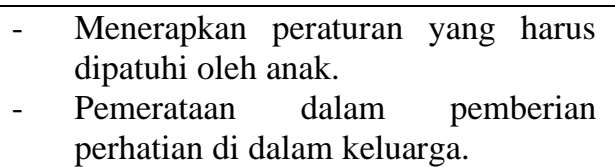 & $\begin{array}{c}\text { Menerapkan disiplin tinggi untuk } \\
\text { menumbuhkan kebiasaan baik } \\
\text { pada anak. }\end{array}$ \\
\hline $\begin{array}{l}\text { Rosita } \\
\text { Herawati }\end{array}$ & 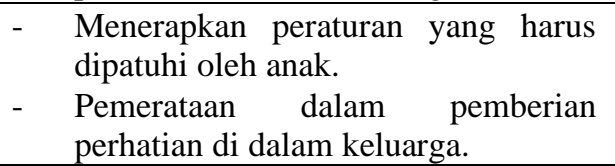 & $\begin{array}{c}\text { Menerapkan disiplin waktu pada } \\
\text { anak. }\end{array}$ \\
\hline
\end{tabular}

Hasil yang didapat melalui wawancara dengan keempat informan utama adalah peran orang tua sebagai komunikator dalam menyampaikan pesan kepada ABK tuna grahita adalah orang tua menerapkan peraturan yang harus dipatuhi oleh anak berkebutuhan khusus tuna grahita yang bertujuan untuk melatih kedisiplinan dan kemandirian ABK nya. Kemudian tidak ada perbedaan dalam pemberian perhatian dalam keluarga antara anak normal dan ABK nya.

Di definisikan ditandai dengan oleh adanya keseragaman dalam sikap, nilai-nilai, dan kepercayaan. Konformitas juga dapat dilihat melalui sisi aturan yang ditetapkan dalam keluarga, biasanya orang tua yang menentukan adanya sebuah aturan di dalam keluarga dan diberikan kepada anak-anaknya. Selain itu, konformitas juga dapat diperhatikan dari sisi pemerataan perhatian dan kesesuaian antara satu dengan anggota keluarga lainnya. Dalam hal ini bisa terjadi adanya kecemburuan antara sesama anggota keluarga. Sebagai contoh seorang ayah dan ibu yang lebih perhatian kepada anak pertamanya dibandingkan anak keduanya. Interaksi ini biasanya berfokus pada harmoni, penghindaran konflik, dan saling ketergantungan dengan anggota keluarga menurut (Koerner \& Fitzpatrick, 2006). Ketiga keluarga yang memiliki konformitas yang tergolong tinggi dengan menerapkan peraturan yang harus dipatuhi oleh anak nya dalam melatih kemandirian, sedangkan terdapat satu keluarga dengan konformitas yang tergolong lemah/rendah memiliki interaksi yang sedikit dengan tidak memaksakan anaknya untuk patuh dalam aturan yang akan melatih kemandirian nya. Aturan yang dibuat bertujuan untuk menumbuhkan kedisiplinan dalam diri anak. Dalam hal pemberian perhatian dari orang tua kepada anak terlihat tidak ada keistimewaan di dalam nya. Sedangkan untuk cara yang orang tua ajarkan kepada anak nya dalam melatih kemandirian selama dirumah dengan memberikan contoh dan membimbing dalam praktek yang dilakukan secara langsung kepada anak nya mulai dari mengajarkan bagaimana cara mandi, makan, menggosok gigi, berpakaian, serta mengenalkan ilmu agama kepada anak. 
Berdasarkan hasil data wawancara pada keempat orang tua anak berkebutuhan khusus tuna grahita di Yayasan Rumah Bersama, di dapat bahwa sebagian keluarga telah menerapkan dimensi konformitas yang tinggi (high conformity), artinya anggota keluarga memiliki peraturan yang dibuat orang tua harus dipatuhi oleh anak berkebutuhan khusus tuna grahita dalam melatih kemandirian. Sedangkan terdapat satu keluarga yang menerapkan dimensi konformitas yang rendah (low conformity), artinya terdapat keseragaman dalam sikap, nilai-nilai, dan kepercayaan dalam keluarga. Satu keluarga memiliki interaksi yang sedikit dengan tidak memaksakan anaknya untuk patuh dalam aturan yang akan melatih kemandirian nya. Aturan yang dibuat bertujuan untuk menumbuhkan kedisiplinan dalam diri anak. Dalam hal pemberian perhatian dari orang tua kepada anak berkebutuhan khusus tuna grahita terlihat tidak ada keistimewaan di dalam nya. Kemandirian melalui konformitas dilakukan seperti orang tua mengajarkan kepada anak nya dalam melatih kemandirian selama dirumah dengan memberikan contoh dan membimbing dalam praktek yang dilakukan secara langsung kepada anak nya mulai dari mengajarkan bagaimana cara mandi, makan, menggosok gigi, berpakaian, serta mengenalkan ilmu agama kepada anak.

Sehingga dapat disimpulkan bahwa peran komunikasi keluarga dalam kemandirian anak berkebutuhan khusus tuna grahita menggunakan pola komunikasi protective families karena ditandai adanya dengan keluarga dengan orientasi percakapan yang rendah dan orientasi konformitas tinggi diberi label protektif.

\section{SIMPULAN}

Kesimpulan yang di dapat adalah komunikasi keluarga dalam membangun kemandirian anak berkebutuhan khusus tuna grahita harus dilakukan dengan metode yang tepat. Peran orang tua dan lingkungan keluarga merupakan faktor yang sangat menentukan keberhasilannya. Komunikasi keluarga melalui orientasi percakapan yang tinggi lebih efektif dalam melatih kemandirian anak berkebutuhan khusus tuna grahita. Hal ini tercermin dalam sikap anggota keluarga yang lebih bebas, intensif dan secara spontan berinteraksi satu sama lain tanpa banyak batasan waktu atau topik yang dibahas. Selain itu melalui komunikasi orientasi konformitas yang tinggi juga cukup efektif dalam mendorong kemandirian anak berkebutuhan khusus tuna grahita. Dengan pola komunikasi tersebut, lingkungan keluarga menciptakan kondisi yang akan mendorong anak berkebutuhan khusus tuna grahita mematuhi aturan yang akan melatih kemandirian.

\section{DAFTAR PUSTAKA}

Al Ansori, A. N. (2020). Jumlah Penyandang Disabilitas di Indonesia Menurut Kementerian Sosial. Liputan 6.com. https://www.liputan6.com/disabilitas/read/4351496/jumlah-penyandang-disabilitas-diindonesia-menurut-kementeriansosial\#: :text=Berdasarkan\%20data\%20Susenas\%20pada\%202018,atau\%2030\%2C38\%20juta\%20 jiwa diakses pada Jum'at, 15 Januari 2021.

Alhafid, S. B. (2018). Pola Komunikasi Antarpribadi Guru dan Siswa Berkebutuhan Khusus dalam Menumbuhkan Kemandirian (Studi di SLB Tunas Harapan Bangsa Balai Kembang Luwu Timur) (Doctoral dissertation, Universitas Islam Negeri Alauddin Makassar). 
Apsari, Y. (2015). No Title. Peran Orang Tua Dalam Mengembangkan Activity of Daily Living Anak Autis $\begin{array}{llllllll}\text { Kelas } & I V & S D & \mathrm{~d} & \mathrm{SLB} \quad \text { Citra Mulia }\end{array}$ http://journal.student.uny.ac.id/jurnal/artikel/14782/87/1510

Aulia. (2016). Orangtua dengan Anak Disabilitas Sering Melupakan Ini. p2ptm.kemkes.go.id. http://www.p2ptm.kemkes.go.id/artikel-penyakit/orangtua-dengan-anak-disabilitas-seringmelupakan-ini diakses pada Jum'at, 15 Januari 2021.

Awi, M. V., Mewengkang, N., \& Golung, A. (2016). Peranan Komunikasi Antar Pribadi Dalam Menciptakan Harmonisasi Keluarga Di Desa Kimaamkabupaten Merauke. Acta Diurna Komunikasi, 5(2).

Basaninyenzi, U. (2020). Disability Inclusion. worldbank.org. https://www.worldbank.org/en/topic/disability diakses pada Kamis 15 Oktober 2020.

Davidson, N., \& Kroll, D. L. (1991). An overview of research on cooperative learning related to mathematics. Journal for Research in Mathematics Education, 22(5), 362-365.

Edemekong, P. F., Bomgaars, D. L., \& Levy, S. B. (2017). Activities of daily living (ADLs).

Hutasoit, M., \& Sartika, S. (2018). Hubungan Peran Orangtua dalam Meningkatkan Kemandirian Activity Daily Living (ADL) pada Anak Retardasi Mental. Journal Center of Research Publication in Midwifery and Nursing, 2(2), 52-57.

Koerner, A. F., \& Fitzpatrick, M. A. (2006). Family communication patterns theory: A social cognitive approach. Engaging Theories in Family Communication: Multiple Perspectives, 50-65.

Kurniawan, E. (2012). Pengaruh Program Bina Diri terhadap Kemandirian Anak Tunagrahita. Psympathic: Jurnal Ilmiah Psikologi, 5(2), 616-628.

Kustiani, R. (2019). Berapa Banyak Penyandang Disabilitas di Indonesia? Simak Data Ini.Tempo.Co. https://difabel.tempo.co/read/1266832/berapa-banyak-penyandang-disabilitas-di-indonesiasimak-data-ini/full\&view=ok pada Jum'at, 15 Januari 2021.

Littlejohn, S. W., \& Foss, K. A. (2009). Encyclopedia of communication theory (Vol. 1). Sage.

Mayasari, N. (2019). Layanan Pendidikan Bagi Anak Tunagrahita Dengan Tipe Down Syndrome. Yinyang: Jurnal Studi Islam Gender Dan Anak, 14(1), 111-134.

Mekarisce, A. A. (2020). Teknik Pemeriksaan Keabsahan Data pada Penelitian Kualitatif di Bidang Kesehatan Masyarakat. Jurnal Ilmiah Kesehatan Masyarakat: Media Komunikasi Komunitas Kesehatan Masyarakat, 12(3), 145-151.

Organization, I. L. (2010). Jumlah Penyandang Disabilitas di Indonesia. https://www.ilo.org/wcmsp5/groups/public/---asia/---ro-bangkok/---ilojakarta/documents/publication/wcms_233426.pdf diakses pada Jum’at, 15 Januari 2021.

Rahmatika, S. N., \& Apsari, N. C. (2020). Positive Parenting: Peran Orang Tua Dalam Membangun Kemandirian Anak Tunagrahita. Prosiding Penelitian Dan Pengabdian Kepada Masyarakat, 7(2), 329-340.

Ramawati, D., Allenidekania, A., \& Besral, B. (2012). Kemampuan perawatan diri anak tuna grahita berdasarkan faktor eksternal dan internal anak. Jurnal Keperawatan Indonesia, 15(2), 89-96.

Tuffour, I. (2017). A critical overview of interpretative phenomenological analysis: A contemporary qualitative research approach. Journal of Healthcare Communications, 2(4), 52.

Ummah, D. M. (2018). Analisis kesulitan belajar pada anak berkebutuhan khusus (ABK) Di SMA Negeri 10 Kota Ternate. Jurnal Bimbingan Dan Konseling Terapan, 2(1).

Widiastuti, N. L. G. K., \& Winaya, I. M. A. (2019). Prinsip Khusus Dan Jenis Layanan Pendidikan Bagi Anak Tunagrahita. Jurnal Santiaji Pendidikan (JSP), 9(2), 116-126. 
Wiryadi, S. S. (2014). Pola Asuh Orang Tua Dalam Upaya Pembentukan Kemandirian Anak Down Syndrome X Kelas D1/C1 di SLB Negeri 2 Padang. Jurnal Penelitian Pendidikan Khusus, 3(3).

Yusuf, A. M. (2016). Metode penelitian kuantitatif, kualitatif \& penelitian gabungan. Prenada Media. 